\title{
Clostridium Tyrobutyricum Protect Intestinal Barrier Function from LPS- Induced Apoptosis via P38/JNK Signaling Pathway in IPEC-J2 Cells
}

\author{
Zhiping Xiao Lujie Liu $^{a}$ Wenjing Tao ${ }^{a}$ Xun Pei ${ }^{a}$ Geng Wang ${ }^{a} \quad$ Minqi Wang ${ }^{a}$ \\ aKey Laboratory of Molecular Animal Nutrition, Ministry of Education, Zhejiang University, Hangzhou, \\ China, Key Laboratory of Animal Nutrition and Feed Science in Eastern China, Ministry of Agriculture, \\ Zhejiang University, Hangzhou, China, Key Laboratory of Feed and Animal Nutrition, Institute of Feed \\ Science, Zhejiang University, Hangzhou, China
}

\section{Key Words}

Clostridium tyrobutyricum • IPEC-J2 - Intestinal barrier function • Apoptosis • P38/JNK signaling pathway

\begin{abstract}
Background/Aims: The intestinal mucosa forms a physical and metabolic barrier against the diffusion of pathogens, toxins, and allergens from the lumen into the circulatory system. Early weaning, a critical phase in swine production, can compromise intestinal barrier function through mucosal damage and alteration of tight junction integrity. Maintenance of intestinal barrier function plays a pivotal role in optimum gastrointestinal health. In this study, we investigated the effects of Clostridium tyrobutyricum (C.t) on intestinal barrier dysfunction induced by lipopolysaccharide (LPS) and the underlying mechanisms involved in intestinal barrier protection. Methods: A Transwell model of IPEC-J2 cells was used to imitate the intestinal barrier. Fluorescence microscopy and flow cytometry were used to evaluate apoptosis. Real-time PCR was used to detect apoptosis-related genes and the downstream genes of the p38/c-Jun N-terminal kinase (JNK) signaling pathways. Western blotting was used to measure the expressions of tight junction proteins and mitogen-activated protein kinases. Results: C.t efficiently maintained trans-epithelium electrical resistance values and intestinal permeability after LPS-induced intestinal barrier disruption. The expressions of tight junction proteins (ZO-1, claudin-1, and occludin) were promoted when IPEC-J2 cells were treated with C.t. Fluorescence imaging and flow cytometry revealed that C.t qualitatively and quantitatively inhibited LPS-induced cell apoptosis. C.t also increased the relative expression of the antiapoptotic gene $\mathrm{Bcl}-2$ and decreased that of the apoptotic genes Bax and caspase-3/-8. Moreover, the protective effect of C.t on damaged intestinal cell models was associated with suppression of p38 and JNK phosphorylation, negative regulation of the relative expressions of downstream genes including AP-1, ATF-2, ELK-1, and p53, and activation of Stat3 expression. Conclusions: These findings indicate that C.t may promote intestinal integrity, suggesting a novel probiotic effect on intestinal barrier function.




\section{Cellular Physiology Cell Physiol Biochem 2018;46:1779-1792

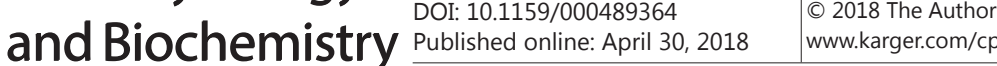 \\ Xiao et al.: C.t Attenuates LPS-Induced Intestial Barrier Dysfunction}

\section{Introduction}

The intestinal epithelial barrier, which is formed by intestinal mucosa, separates the internal milieu from the external environment and is the first line of defense against bacterial and toxin invasion of host tissues [1, 2]. At early weaning, the intestinal barrier function of pigs is vulnerable to damage. The epithelial layer impairment results in poor nutrient digestion and absorption, reduced transmucosal resistance, imbalanced secretion and absorption of water and electrolytes, and increased enteric pathogen infection. Disruption of the intestinal barrier disturbs immune homeostasis, increases inflammation in the intestine, and is associated with intestinal diseases such as diarrhea [3-5]. Therefore, maintenance of intestinal barrier function plays a pivotal role in optimum gastrointestinal health.

Probiotics, defined as live microorganisms, can maintain epithelial integrity and barrier function, stimulate the cellular repair mechanism, and reestablish well-balanced indigenous intestinal and respiratory microbial communities [6]. Probiotics such as Lactobacillus and Enterococcus faecium help to protect the intestinal epithelium after infection with E. coli or exposure to lipopolysaccharide (LPS) [7, 8]. LPS, produced by Gram-negative bacteria, plays important roles in the integrity of the outer membrane permeability barrier and participates extensively in host-pathogen interplay [9]. LPS interacts with and activates Tolllike receptors, which themselves activate mitogen-activated protein kinases (MAPK) [10]. The MAPK family can be classified into extracellular signal-regulated kinase (ERK), c-Jun N-terminal kinase (JNK), and p38. Signaling by these pathways govern fundamental cellular responses, such as cell proliferation, differentiation, inflammation, and apoptosis [11-12].

Clostridium tyrobutyricum(C.t), a Gram-positive anaerobic bacterium, can efficiently produce butyric acid and is a promising probiotic to protect intestinal epithelial function. Therefore, in this study, we investigated whether C.t could protect porcine intestinal epithelial barrier function, hypothesizing that its benefit might be associated with the MAPK signaling pathway in IPEC-J2 cells.

\section{Materials and Methods}

\section{Cell culture and C.t preparation}

Intestinal porcine epithelial cells (IPEC-J2) were obtained from the Institute of Subtropical Agriculture (Chinese Academy of Sciences) and cultured in Dulbecco's modified Eagle medium/F12 medium (Biological Industries, Kibbutz Beit Haemek, Israel) supplemented with 10\% fetal bovine serum (Gemini, USA), 100 $\mathrm{U} / \mathrm{mL}$ penicillin, and $100 \mu \mathrm{g} / \mathrm{mL}$ streptomycin (Biological Industries, Kibbutz Beit Haemek, Israel) at $37^{\circ} \mathrm{C}$ with $5 \% \mathrm{CO}_{2}$ in a humidified atmosphere. No antibiotics were used during the treatment. C.t was obtained from Ohio State University and cultured anaerobically at $37^{\circ} \mathrm{C}$ in clostridial growth medium (CGM) [13]. C.t was then collected after centrifugation at 12, $000 \mathrm{rpm}$ for $5 \mathrm{~min}$, washed 3 times, and suspended in phosphate-buffered saline(PBS) at different concentrations $\left(10^{6}\right.$ to $\left.10^{11} \mathrm{CFU} / \mathrm{mL}\right)$ for cell treatments.

\section{Cell viability and cytotoxicity assay}

Cell viability following treatment with different concentrations of C.t (ranging from $10^{6}$ to $10^{11} \mathrm{CFU} /$ $\mathrm{mL}$ ) for different hours $(2,4,6,8$, and $10 \mathrm{~h}$ ) was measured using the Cell Counting Kit 8 (MedChem Express, Monmouth Junction, NJ, USA). Cell cytotoxicity following the treatments with different concentrations of $C . t$ (ranging from $10^{8}$ to $10^{11} \mathrm{CFU} / \mathrm{mL}$ ) for $8 \mathrm{~h}$ was measured using a lactate dehydrogenase (LDH) detection kit (Beyotime, Shanghai, China) according to the manufacturer's instructions. Briefly, IPEC-J2 cells were seeded in 96-well plates at a density of $1 \times 10^{4}$ cells/well, cultured overnight to allow cell attachment, and then pretreated with C.t after reaching 70-80\% confluence. To evaluate cell viability, $10 \mu \mathrm{L}$ of the Cell Counting Kit 8 assay solution was added to each treated cell well and the cells were further incubated for 1 to $2 \mathrm{~h}$. Subsequently, the optical density was measured using SpectraMax M5 (Molecular Devices, California, USA) at a $450 \mathrm{~nm}$ wavelength, and the percentage of living cells was calculated as described by Mosmann [14]. As for cell cytotoxicity, $150 \mu \mathrm{L} \mathrm{LDH}$ release solution was added to each cell well and incubated for $1 \mathrm{~h}$. Next, 120 $\mu \mathrm{L}$ cell-free culture supernatants were collected into new 96-well plates after centrifugation at 1, $200 \mathrm{rpm}$ 


\section{Cellular Physiology Cell Physiol Biochem 2018;46:1779-1792 \begin{tabular}{ll|l} 
and Biochemistry & $\begin{array}{l}\text { DOI: 10.1159/000489364 } \\
\text { Published onIIne: April 30, } 2018\end{array}$ & $\begin{array}{l}\text { () 2018 The Author(s). Published by S. Karger AG, Basel } \\
\text { www.karger.com/cpb }\end{array}$ \\
\cline { 2 - 3 }
\end{tabular}}

Xiao et al.: C.t Attenuates LPS-Induced Intestial Barrier Dysfunction

for $5 \mathrm{~min}$. Finally, $60 \mu \mathrm{L} \mathrm{LDH}$ working assay solution was added to each cell well and the optical density was measured using the SpectraMax M5 at a $490 \mathrm{~nm}$ wavelength with a reference wavelength of $620 \mathrm{~nm}$ [15].

\section{Trans-epithelium electrical resistance measurements}

IPEC-J2 cells were seeded onto polycarbonate membrane filters $\left(0.4-\mu \mathrm{m}\right.$ pore size, $1.12 \mathrm{~cm}^{2}$ growth area) inside Transwell ${ }^{\circledR}$ cell culture chambers (Corning Costar, Cambridge, MA, USA) at a density of $1 \times 10^{5}$ cells $/ \mathrm{cm}^{2}$. The culture medium was changed every day and trans-epithelium electrical resistance (TEER) values were measured every other day using the Millicell Electrical Resistance System (Millipore ERS-2, Massachusetts, USA). When a monolayer of cells was considered to be completely differentiated as previously described [16], cells were treated with PBS, LPS (LPS;1 $\mu \mathrm{g} / \mathrm{mL}$; LPS 055:B55, Sigma, Massachusetts, USA), C.t, LPS + C.t (cells were treated with $1 \mu \mathrm{g} / \mathrm{mL}$ LPS, followed by C.t), or C.t + LPS (cells treated with C.t, followed by $1 \mu \mathrm{g} / \mathrm{mL} \mathrm{LPS}$ ), and the TEER values were measured every $4 \mathrm{~h}$.

\section{Cell permeability to FD4}

Immediately after the last TEER value measurement, $100 \mu \mathrm{L}$ of $1 \mathrm{mg} / \mathrm{mL} 4-\mathrm{kDa}$ fluorescein isothiocyanate-dextran (FD4; Sigma-Aldrich, St. Louis, MO, USA) was added into the upper compartments of the Transwells. The Transwells were cultured at $37^{\circ} \mathrm{C}$ for $30 \mathrm{~min}$. Then, $100 \mu \mathrm{L}$ of medium of each well from the lower compartments of the Transwells was added into wells of a black 96-well plate and the fluorescence intensity was detected using a SpectraMax M5 at an excitation wavelength of $480 \mathrm{~nm}$ and emission wavelength of $520 \mathrm{~nm}$ [17].

\section{Cell apoptosis detection}

Apoptotic IPEC-J2 cells were detected using an Annexin V-FITC/PI kit (R\&D Systems, Minnesota, USA) according to the manufacturer's instructions. Cells at a density of $1 \times 10^{6}$ cells/well were seeded in 6-well plates overnight. After the treatments were finished, $500 \mu \mathrm{L}$ of $1 \times$ Binding Buffer, $5 \mu \mathrm{L}$ Annexin V-FITC, and $5 \mu \mathrm{L}$ propidium iodide (PI) were added into each well after two washes with PBS and the plates were incubated for $15 \mathrm{~min}$ at room temperature in the dark. Fluorescence images were taken by a TE2000 fluorescence microscope (Nikon, Tokyo,Japan). To determine apoptotic cells by flow cytometry, cells at a density of $1 \times 10^{6}$ cells/well were seeded in 6-well plates overnight. The medium and cells were digested by pancreatin without ethylenediaminetetraacetic acid (EDTA) (Beyotime), collected into 10-mL centrifugal tubes, and centrifuged for $5 \mathrm{~min}$ at 1, $000 \mathrm{rpm}$. Cells were then suspended in $100 \mu \mathrm{L} 1 \times$ Binding Buffer at a concentration of $1 \times 10^{5}$ cells $/ \mathrm{mL}$ in 10 -mL centrifugal tubes. Next, $5 \mu \mathrm{L}$ FITC Annexin V and $5 \mu \mathrm{L}$ PI were added into the tubes and they were incubated for $15 \mathrm{~min}$ at room temperature in the dark. Finally, $400 \mu \mathrm{L} 1$ $\times$ Binding Buffer was added to each tube and cell apoptosis was analyzed by flow cytometry (FACSCalibur, B\&D, Minnesota, USA) within $1 \mathrm{~h}$.

\section{Western blot analysis}

Cells cultured in Transwells and 6-cell culture plates were first digested with $0.25 \%$ trypsin/EDTA (Biological Industries, Kibbutz Beit Haemek, Israel) into centrifuge tubes. Total cell protein was extracted using the Whole Cell Lysis Assay Kit (KeyGEN BioTech, Beijing, China) after two PBS washes. The protein concentration was determined using the BCA Assay Kit (KeyGEN BioTech). Approximately $30 \mu \mathrm{g}$ of protein was boiled in $5 \times$ loading buffer (Sangon Biotech, Shanghai, China), separated by sodium dodecyl sulfate polyacrylamide gel electrophoresis, and then transferred to polyvinylidene fluoride membranes (Millipore, Massachusetts, USA). The membranes were blocked with $5 \%$ non-fat milk for $1 \mathrm{~h}$ at room temperature and then incubated in the corresponding primary antibodies at $4{ }^{\circ} \mathrm{C}$ overnight. After being washed with TBST 3 times for 10 mineach, the membranes were incubated with secondary antibodies for $1 \mathrm{~h}$ at room temperature. The membranes were then washed with TBST as before. The immunoreactive bands were visualized with ECL luminescence reagent (KeyGEN BioTech) using a ChemiScope Touch (Clinx, Shanghai, China). The band intensities were determined using ImageJ software. Primary antibodies ZO-1, Claudin-1, and Occluding were purchased from Proteintech (Wuhan,China). ERK1/2, phospho-ERK1/2, p-38, phospho-p38, JNK, phospho-JNK, and HRP-conjugated anti-rabbit IgG were obtained from Cell Signaling Technology (Massachusetts, USA). $\beta$-actin was purchased from Abcam (Massachusetts, USA), and HRPconjugated anti-mouse IgG was obtained from Beyotime. 


\section{Cellular Physiology Cell Physiol Biochem 2018;46:1779-1792 \begin{tabular}{l|l} 
and Biochemistry $10.1159 / 000489364$ & $\begin{array}{l}\text { P } 2018 \text { The Author(s). Published by S. Karger AG, Basel } \\
\text { www.karger.com/cpb }\end{array}$ \\
\hline
\end{tabular} \\ Xiao et al.: C.t Attenuates LPS-Induced Intestial Barrier Dysfunction}

\section{Real-time PCR}

Total RNA was extracted using TRIzol reagent (Invitrogen, Carlsbad, California, USA). RNA quantity and quality were determined using a NanoDrop 2000 spectrophotometer (Thermo Fisher Scientific, Massachusetts, USA). cDNA was synthesized with the PrimeScript RT reagent kit with gDNA Eraser (TAKARA, Dalian, China) according to the manufacturer's instructions. Briefly, $1 \mu \mathrm{g}$ total RNA was used to erase gDNA at $42{ }^{\circ} \mathrm{C}$ for $2 \mathrm{~min}$. The reverse transcription was conducted at $37{ }^{\circ} \mathrm{C}$ for $15 \mathrm{~min}$ and $85{ }^{\circ} \mathrm{C}$ for $5 \mathrm{~s}$. Real-time PCR was performed on a CFX96TM Real-Time System (BioRad, Hercules, CA, USA) in triplicate, in a total volume of $25 \mu \mathrm{L}$ consisting of $12.5 \mu \mathrm{L}$ SYBR Premix EX Taq (TAKARA), $0.5 \mu \mathrm{L}$ of each primer $(10 \mu \mathrm{M})$, $2 \mu \mathrm{L}$ of cDNA template, and $9.5 \mu \mathrm{L}$ double-distilled water. The PCR cycle conditions were $95^{\circ} \mathrm{C}$ for 30 $\mathrm{s}$, followed by 40 cycles of $95^{\circ} \mathrm{C}$ for $5 \mathrm{~s}$ and $60^{\circ} \mathrm{C}$ for $30 \mathrm{~s}$. Melting curve analysis was used to confirm the specificity and reliability of the PCR products. $\beta$-actin was used as a house-keeping gene to normalize target gene levels. The relative mRNA expression was calculated using the $2^{-\Delta \Delta c t}$ method [18]. Primers used in this study were designed with Primer 5.0 (Table 1) and synthesized in Tsingke (Beijing, China).

\section{Statistical analysis}

Statistical analysis was performed with one-way analysis of variance followed by a Duncan multiple range test with SPSS 17.0 (SPSS, Chicago, IL, USA). All data are expressed as the mean \pm standard error of the mean (SEM). Differences were considered significant at $\mathrm{P}<0.05$.

\section{Results}

C.t boosted cell viability and reduced cytotoxicity in IPEC-J2 cells

IPEC-J2 cells were treated with C.t at different final concentrations (ranging from $10^{6}$ to $10^{11} \mathrm{CFU} / \mathrm{mL}$ ) for $2,4,6,8$, and $10 \mathrm{~h}$. As shown in Fig. 1A, C.t treatment enhanced the growth of IPEC-J2 cells in a dose- and time-dependent manner. For instance, cell viability was increased significantly at $8 \mathrm{~h}(\mathrm{P}<0.001)$. When cells were treated with high concentrations (ranging from $10^{8}$ to $10^{11} \mathrm{CFU} / \mathrm{mL}$ ), cell viability was increased significantly compared with other concentrations $(\mathrm{P}<0.05)$ (Fig. 1A). Cell cytotoxicity was measured after cells were treated with C.t (ranging from $10^{8}$ to $10^{11} \mathrm{CFU} / \mathrm{mL}$ ) for $8 \mathrm{~h}$, with the results showing that $\mathrm{LDH}$ release was decreased when cells were treated with $10^{8}$ and $10^{9} \mathrm{CFU} / \mathrm{mL}$ C.t compared with the control ( $\mathrm{P}<0.01$; Fig. 1B). Therefore, IPEC-J2 cells treated with $10^{8} \mathrm{CFU} / \mathrm{mL}$ C.t for $8 \mathrm{~h}$ were used in the subsequent experiments.

\section{C.t maintained permeability in IPEC-J2 cells}

An intestinal barrier model was used to investigate whether C.t could inhibit the in vitro LPS-induced increase in intestinal permeability. When the TEER value reached $1524.43 \pm$ $15.02 \Omega \cdot \mathrm{cm}^{2}$, the monolayer was considered to be completely differentiated (Fig. 2A). Cells were treated with PBS (the control), LPS, C.t, LPS + C.t, or C.t + LPS (Fig. 2B), and TEER measurements were conducted every 4 hours. The TEER value reduced to the lowest $(\sim 40$ $\Omega \cdot \mathrm{cm}^{2}$ ) in $20 \mathrm{~h}$ with LPS treatment, indicating that the intestinal integrity was greatly disturbed. No significant differences were detected between the control and the C.t treatment, implying that $C . t$ positively maintained the TEER values of IPEC-J2 cells with time. As for the LPS + C.t treatment, the TEER value decreased to $217 \Omega \cdot \mathrm{cm}^{2}$ in the first $12 \mathrm{~h}$ when cells were pretreated with LPS. However, the TEER value was maintained at about $223 \Omega \cdot \mathrm{cm}^{2}$ after the 


\section{Cellular Physiology \\ Cell Physiol Biochem 2018;46:1779-1792 and Biochemistry

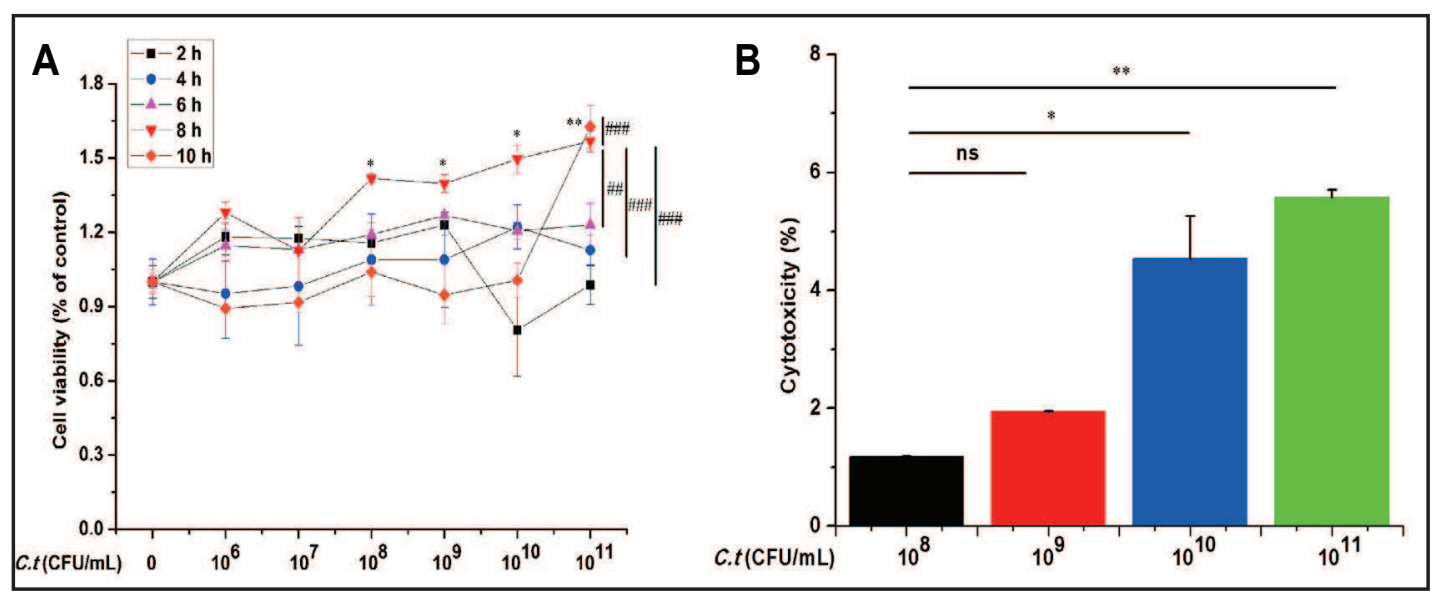

Fig. 1. Cell viability and cytotoxicity of Clostridium tyrobutyricum (C.t) in IPEC-J2 cells. (A) Cell viability of cells treated with different concentrations $\left(10^{6}, 10^{7}, 10^{8}, 10^{9}, 10^{10}, 10^{11} \mathrm{CFU} / \mathrm{mL}\right)$ of $C . t$ for different $0,2,4$, 6, 8, $10 \mathrm{~h}$. (B) Cell cytotoxicity of cells treated with different concentrations $\left(10^{8}, 10^{9}, 10^{10}, 10^{11} \mathrm{CFU} / \mathrm{mL}\right)$ of C.t for different $8 \mathrm{~h}$. Data were expressed as mean \pm SEM $(\mathrm{n}=3)$. ${ }^{\mathrm{n}} \mathrm{P}>0.05,{ }^{*} \mathrm{P}<0.05,{ }^{* *} \mathrm{P}<0.01$ and ${ }^{* * *} \mathrm{P}<0.001$ compared with the control; ${ }^{\text {ns }} \mathrm{P}>0.05$, ${ }^{\#} \mathrm{P}<0.05$, ${ }^{\# \#} \mathrm{P}<0.01$, "\#\# $\mathrm{P}<0.001$ compared with LPS. ,Results represented one of the three independent experiments.

cells were treated with $C . t$ in the next 8 h. For the cells treated with $C . t+$ LPS, the TEER value was the same as the control when the cells were pretreated with C.t in the first $8 \mathrm{~h}$, whereas the TEER value reached the minimum after LPS was added in the next $12 \mathrm{~h}$ (Fig. $2 \mathrm{C}$ ).

After the TEER values were measured, FD4 was added into the upper compartments of the Transwells to ensure that C.t could suppress the LPS-induced increase in intestinal permeability. The concentration of FD4 was markedly increased by LPS treatment compared with the control and C.t treatment groups $(\mathrm{P}<0.01)$ and no differences were observed between the control and C.t-treated cells. In addition, the concentrations of FD4 were decreased by the LPS + C.t and C.t + LPS treatments compared with LPS alone $(\mathrm{P}<0.01$; Fig. 2D).

The expressions of tight junction (TJ) proteins (ZO-1, Claudin-1, and Occludin) were also measured in this study. After treatment with LPS or C.t for $20 \mathrm{~h}$, the expressions of TJ proteins were significantly decreased in cells treated with LPS $(\mathrm{P}<0.05)$, whereas $C . t$ increased the expressions of all three proteins $(\mathrm{P}<0.01)$. In addition, we noted that $C . t$ inhibited the LPSinduced decrease in TJ protein expressions (Fig. 2E-G).

\section{C.t improved the expression of TJ proteins in IPEC-J2 cells}

TJ protein expressions were measured to further investigate the protective effect of $C . t$ on the intestinal barrier. Compared with the control, cells treated with LPS alone for $12 \mathrm{~h}$ showed decreased expressions of TJ proteins $(\mathrm{P}<0.01$; Fig. 3$)$, which was consistent with the TEER, FD4, and TJ protein expression results obtained previously (Fig. 2). No differences could be observed between the control and 8-hC.t treatment groups in the expressions of ZO-1 and Claudin-1, but Occludin expression was much higher in the C.t group than in the control $(\mathrm{P}<0.01)$. Cells treated with LPS + C.t showed increased expression of these three proteins compared with the LPS-alone group, whereas the expressions of TJ proteins werenot different between the C.t + LPS and LPS treatments.

\section{C.t suppressed LPS-induced cell apoptosis in IPEC-J2 cells}

The bright-field images of cells pretreated with LPS showed nuclear and cytoplasmic condensation and some cellular fragments, which are typical characteristics of apoptosis. However, there was no characteristic difference between the control and C.t treatment groups (Fig. 4A). An annexin V-FITC/PI assay was conducted to further confirm whether C.t could attenuate LPS-induced apoptosis. Fluorescence images of FITC-/PI-stained apoptotic 


\section{Cellular Physiology Cell Physiol Biochem 2018;46:1779-1792 \begin{tabular}{l|l|l} 
DOI: 10.1159/000489364 & () 2018 The Author(s). Published by S. Karger AG, Basel \\
www.karg Biochemistry Published
\end{tabular} \\ Xiao et al.: C.t Attenuates LPS-Induced Intestial Barrier Dysfunction}

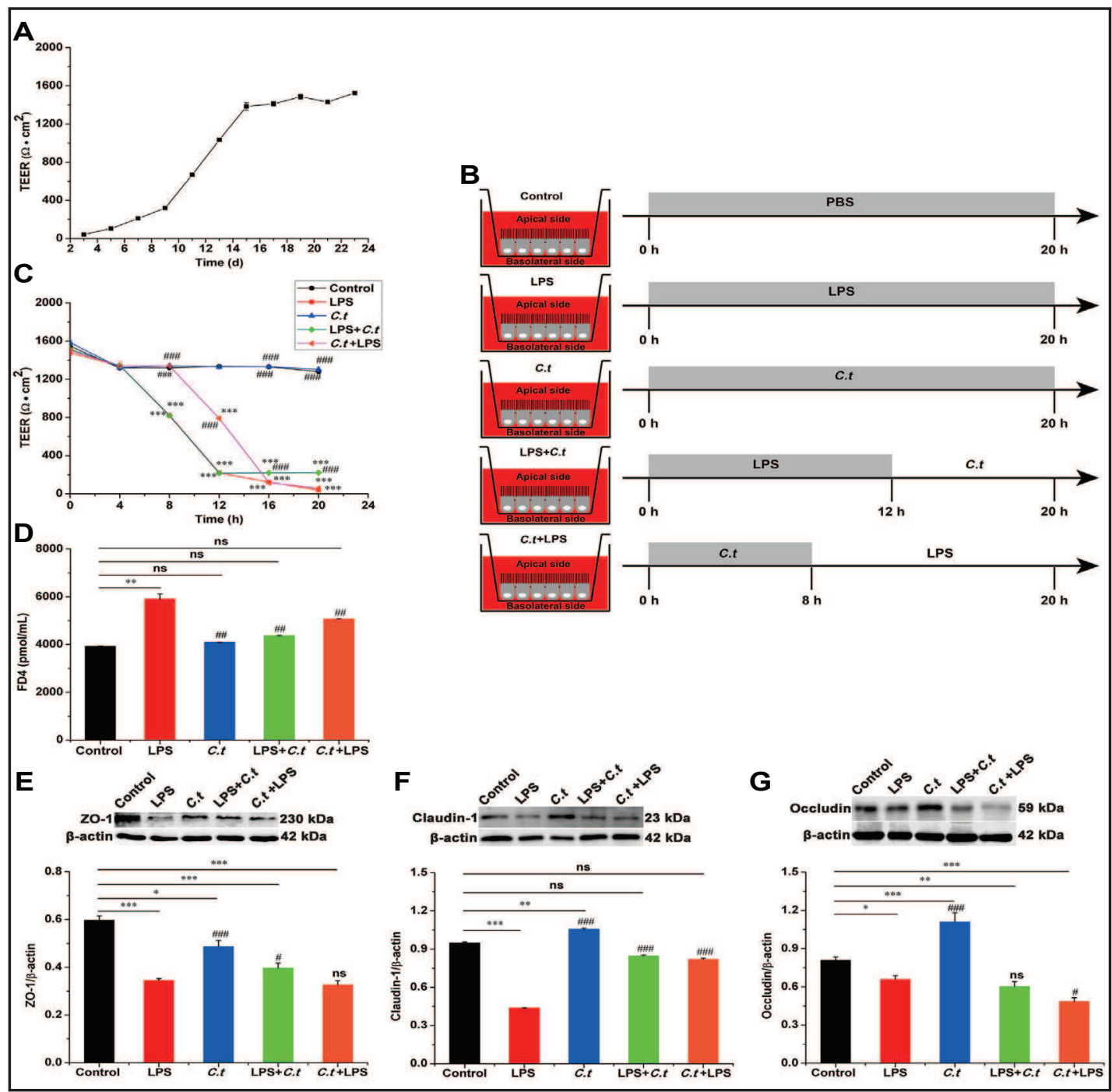

Fig. 2. Effect of Clostridium tyrobutyricum (C.t) on IPEC-J2 cells permeability. Cells were treated with PBS (the control), LPS $(1 \mu \mathrm{g} / \mathrm{mL}$ for $20 \mathrm{~h})$, C.t $\left(10^{8} \mathrm{CFU} / \mathrm{mL}\right.$ for $\left.20 \mathrm{~h}\right)$, LPS + C.t $(1 \mu \mathrm{g} / \mathrm{mL}$ LPS for $12 \mathrm{~h}$ followed by $10^{8} \mathrm{CFU} / \mathrm{mL}$ C.t for $\left.8 \mathrm{~h}\right)$, or C.t + LPS $\left(10^{8} \mathrm{CFU} / \mathrm{mL}\right.$ C.t for $8 \mathrm{~h}$ followed by $1 \mu \mathrm{g} / \mathrm{mL}$ LPS for $\left.12 \mathrm{~h}\right)$ after IPEC-J2 cells were completely differentiated in the transwells. (A) Changes in the TEER values of IPEC-J2 cells over time for the completely differentiated monolayer; (B) Schematic illustration of the in vitro intestinal barrier model using transwells to evaluate the effects of C.t on intestinal permeability; (C) Effect of C.t on the LPSinduced TEER decrease in IPEC-J2 cells; (D) Effect of C.t on IPEC-J2 cells permeability to FD4; (E-G) Western blot and quantitative analysis of the expressions of ZO-1, Claudin-1, and Occludin. Data were expressed as mean \pm SEM $(n=5)$. ${ }^{n s} \mathrm{P}>0.05,{ }^{*} \mathrm{P}<0.05,{ }^{* *} \mathrm{P}<0.01$ and ${ }^{* * *} \mathrm{P}<0.001$ compared with the control; ${ }^{\text {ns }} \mathrm{P}>0.05,{ }^{\#} \mathrm{P}<0.05$,

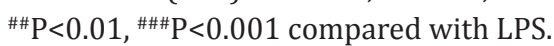

IPEC-J2 cells showed that LPS considerably stimulated cell apoptosis. No differences were observed between the control and C.t treatments. Both LPS + C.t and C.t + LPS treatments partially inhibited the LPS-induced apoptosis (Fig. 4B).

The results of flow cytometry quantitatively verified the above results. LPS significantly increased $(\mathrm{P}<0.05)$ the ratio of apoptotic cells, whereas C.t efficiently inhibited apoptosis induced by LPS (Fig. 4C). The flow cytometry results showed that $57.47 \%$ cells were alive when the cells were treated LPS alone, which was lower than the percentages in the control and C.t groups (94.4\% live cells and 96.8\% live cells, respectively; $\mathrm{P}<0.001$; Fig. 4D and E). 


\section{Cellular Physiology Cell Physiol Biochem 2018;46:1779-1792

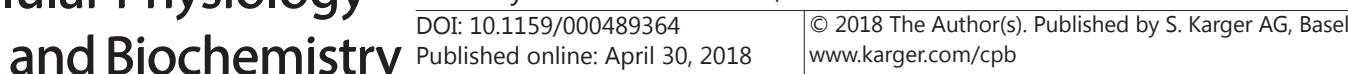

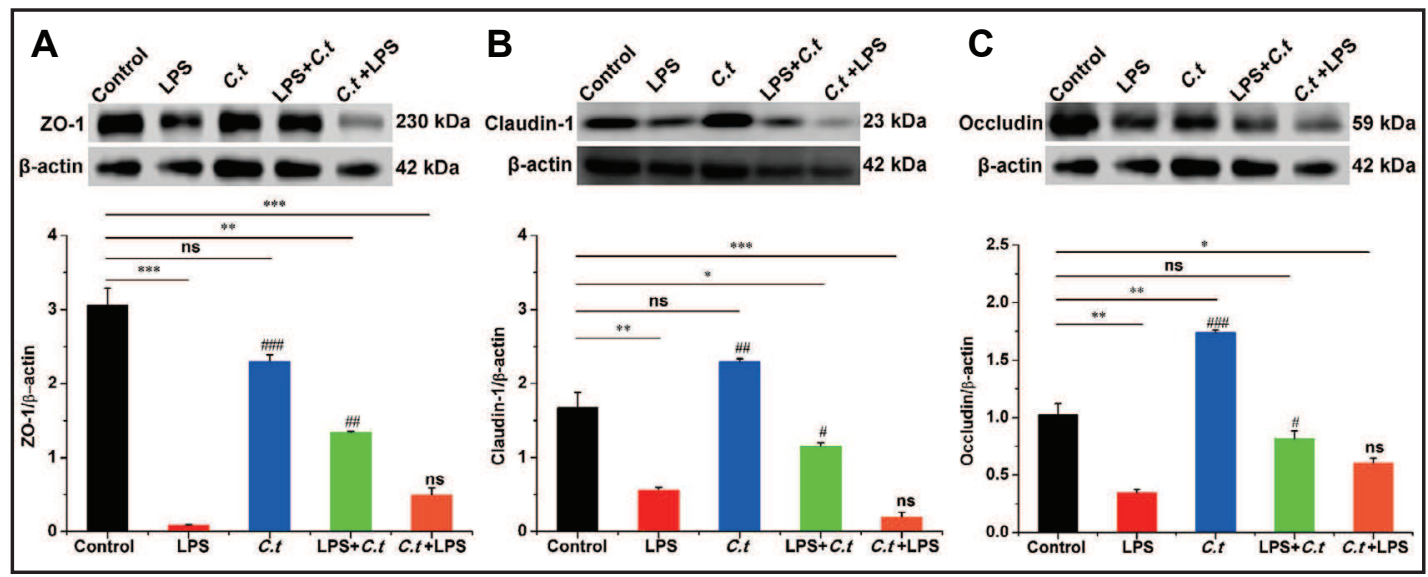

Fig. 3. Effect of Clostridium tyrobutyricum (C.t) on the expressions of tight junction proteins in IPEC-J2 cells. Cells were cultured in 6-wells plates for $24 \mathrm{~h}$ and then treated with PBS (the control), LPS ( $1 \mu \mathrm{g} / \mathrm{mL}$ for 12 h), C.t $\left(10^{8} \mathrm{CFU} / \mathrm{mL}\right.$ for $\left.8 \mathrm{~h}\right)$, LPS + C.t $\left(1 \mu \mathrm{g} / \mathrm{mL}\right.$ LPS for $12 \mathrm{~h}$ followed by $10^{8} \mathrm{CFU} / \mathrm{mL}$ C.t for $\left.8 \mathrm{~h}\right)$, or C.t + LPS $\left(10^{8} \mathrm{CFU} / \mathrm{mL}\right.$ C.t for $8 \mathrm{~h}$ followed by $1 \mu \mathrm{g} / \mathrm{mL}$ LPS for $\left.12 \mathrm{~h}\right)$. (A-C) Western blot and quantitative analysis of the expressions of Z0-1, Claudin- 1 , and Occludin. Data were expressed as mean $\pm S E M(n=3)$. ${ }^{n} P>0.05$, ${ }^{*} \mathrm{P}<0.05,{ }^{* *} \mathrm{P}<0.01$ and ${ }^{* * *} \mathrm{P}<0.001$ compared with the control; ${ }^{\mathrm{n}} \mathrm{P}>0.05,{ }^{\#} \mathrm{P}<0.05,{ }^{\# \#} \mathrm{P}<0.01,{ }^{\# \# \#} \mathrm{P}<0.001$ compared with LPS. Results represented one of the three independent experiments.

Fig. 4. Effect of Clostridium tyrobutyricum (C.t) on LPS-induced apoptosis in IPEC-J2 cells. Cells were cultured in 6-wells plates for $24 \mathrm{~h}$ and then treated with PBS (the control), LPS $(1 \mu \mathrm{g} / \mathrm{mL}$ for 12 h), C.t $\left(10^{8} \mathrm{CFU} / \mathrm{mL}\right.$ for $\left.8 \mathrm{~h}\right)$, LPS + C.t $(1 \mu \mathrm{g} / \mathrm{mL}$ LPS for $12 \mathrm{~h}$ followed by $10^{8} \mathrm{CFU} / \mathrm{mL}$ C.t for $8 \mathrm{~h}$ ), or C.t + LPS $\left(10^{8} \mathrm{CFU} / \mathrm{mL}\right.$ C.t for $8 \mathrm{~h}$ followed by $1 \mu \mathrm{g} / \mathrm{mL}$ LPS for $12 \mathrm{~h}$ ). (A) Representative microscopy images of IPEC-J2 cells under the condition of bright field. The scale bar represents $100 \mu \mathrm{m}$; (B) Fluorescence images of Annexin V-FITC/PI staining apoptotic cells. The scale bar represents $100 \mu \mathrm{m}$; (C) Flow cytometry analysis of Annexin VFITC/PI staining apoptotic cells; (D) Quantification of apoptotic cells (Q2+Q3); (E) Quantification of death cells $(\mathrm{Q} 1+\mathrm{Q} 2+\mathrm{Q} 3)$. Data were expressed as mean \pm SEM $(\mathrm{n}=3)$. ${ }^{\mathrm{n}} \mathrm{P}>0.05,{ }^{*} \mathrm{P}<0.05,{ }^{* *} \mathrm{P}<0.01$ and ${ }^{* * *} \mathrm{P}<0.001$ compared with the control; ${ }^{\text {ns }} \mathrm{P}>0.05$, $\quad{ }^{\#} \mathrm{P}<0.05$, \#\# $\mathrm{P}<0.01$, \#\# $\mathrm{P}<0.001 \quad$ compared with LPS. Results represented one of the three independent experiments.

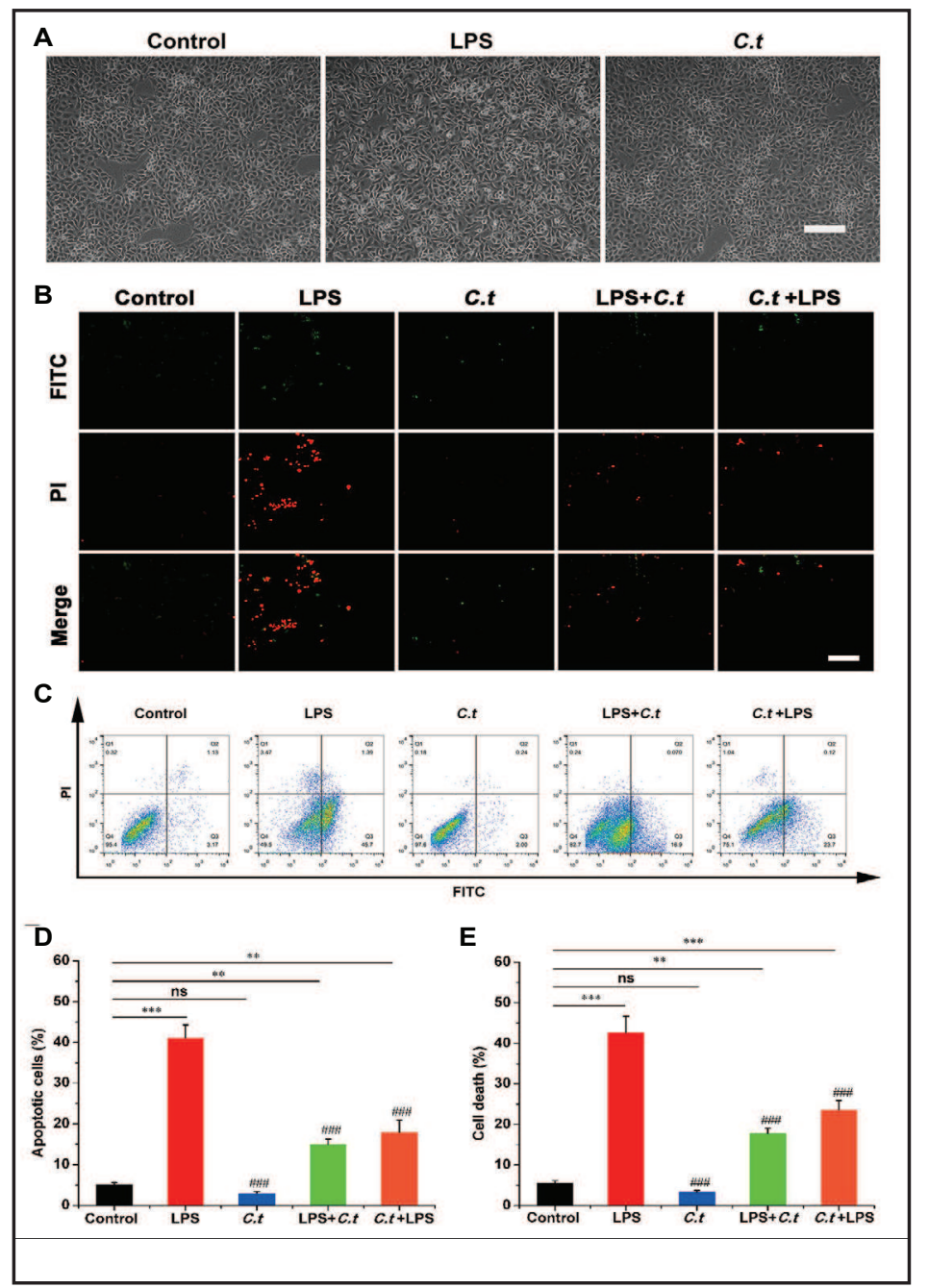

\section{KARGER}




\section{Cellular Physiology Cell Physiol Biochem 2018;46:1779-1792 \begin{tabular}{l|l|l} 
DOI: 10.1159/000489364 & 02018 The Author(s). Published by S. Karger AG, Basel
\end{tabular} \\ Xiao et al.: C.t Attenuates LPS-Induced Intestial Barrier Dysfunction}

Fig. 5. Effect of Clostridium tyrobutyricum (C.t) on mRNA relative expressions of cell apoptosis related genes in IPEC-J2 cells. Cells were cultured in 6-wells plates for $24 \mathrm{~h}$ and then treated with PBS (the control), LPS ( $1 \mu \mathrm{g} / \mathrm{mL}$ for 12 h), C.t $\left(10^{8} \mathrm{CFU} / \mathrm{mL}\right.$ for 8 h), LPS + C.t $(1 \mu \mathrm{g} / \mathrm{mL} \mathrm{LPS}$ for $12 \mathrm{~h}$ followed by $10^{8}$ $\mathrm{CFU} / \mathrm{mL}$ C.t for 8 h), or C.t + LPS $\left(10^{8} \mathrm{CFU} / \mathrm{mL}\right.$ C.t for 8 $\mathrm{h}$ followed by $1 \mu \mathrm{g} / \mathrm{mL}$ LPS for $12 \mathrm{~h}$ ). (A) mRNA relative expression of the antiapoptotic gene Bcl-2; (B) mRNA relative expression of the pro-apoptotic gene

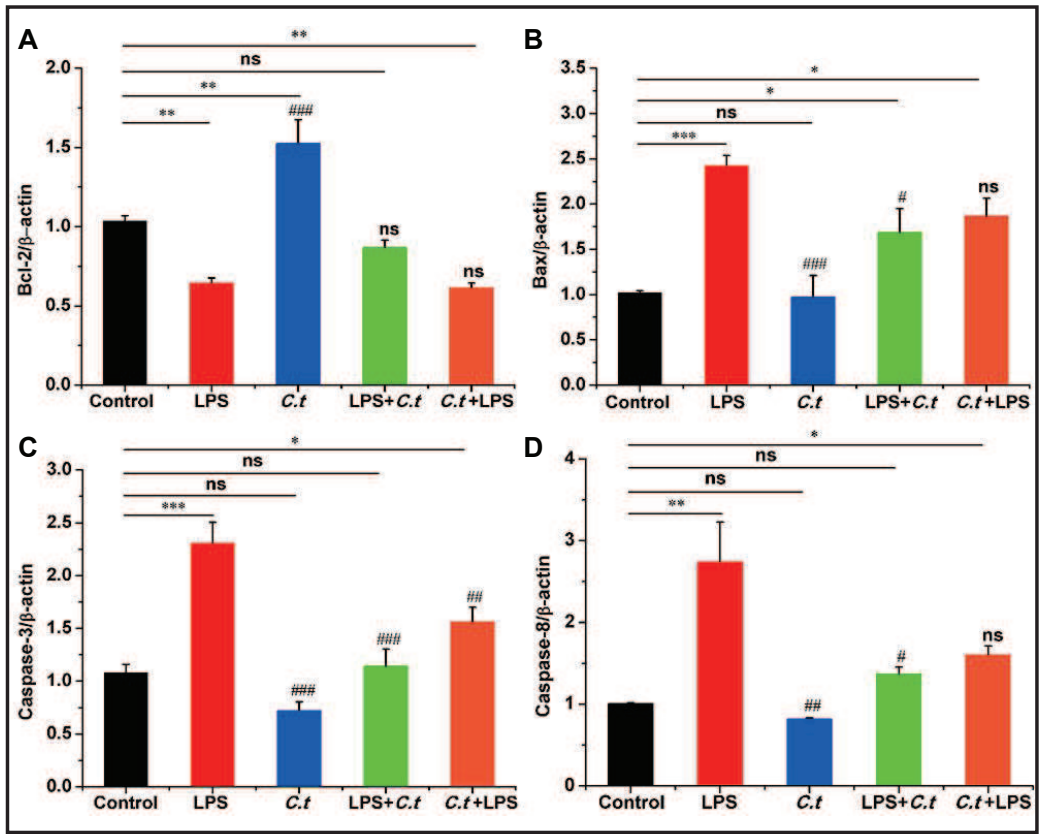
Bax; (C-D) mRNA relative expressions of apoptotic genes Caspase-3/8. Data were expressed as mean $\pm S E M(n=3) .{ }^{n s} P>0.05,{ }^{*} P<0.05$, ${ }^{* *} \mathrm{P}<0.01$ and ${ }^{* * *} \mathrm{P}<0.001$ compared with the control; ${ }^{\text {ns } \mathrm{P}>0.05}$, ${ }^{\#} \mathrm{P}<0.05,{ }^{\# \#} \mathrm{P}<0.01,{ }^{\# \# \#} \mathrm{P}<0.001$ compared with LPS. Results represented one of the three independent experiments.

Fig. 6. Clostridium tyrobutyricum $(C . t)$ protects intestinal barrier from LPS-induced apoptosis in IPEC-J2 cells. Cells were cultured in 6-wells plates for $24 \mathrm{~h}$ and then treated with PBS (the control), LPS $(1 \mu \mathrm{g} /$ $\mathrm{mL}$ for $12 \mathrm{~h})$, C.t $\left(10^{8} \mathrm{CFU} / \mathrm{mL}\right.$ for 8 h), Apoptosis inhibitor + LPS (50 $\mu \mathrm{M}$ apoptosis inhibitor for $1 \mathrm{~h}$ followed by $1 \mu \mathrm{g} / \mathrm{mL}$ for $12 \mathrm{~h}$ ), or Apoptosis inhibitor $(50 \mu \mathrm{M}$ apoptosis inhibitor for $1 \mathrm{~h}$ ). (A) mRNA relative expressions of cell apoptosis related genes; (B-C) Western blot and quantitative analysis of the expressions of ZO1, Claudin-1, and Occludin. Apoptosis inhibitor Z-VAD(OMe)-FMK was purchased from MedChem Express, Monmouth Junction, NJ, USA. Data were expressed as mean \pm SEM $(\mathrm{n}=5)$. ${ }^{\mathrm{n} s} \mathrm{P}>0.05, \quad{ }^{*} \mathrm{P}<0.05,{ }^{* *} \mathrm{P}<0.01$ and ${ }^{* * *} \mathrm{P}<0.001$ compared with the control; ${ }^{\text {ns }} \mathrm{P}>0.05$, ${ }^{\#} \mathrm{P}<0.05$, ${ }^{\# \#} \mathrm{P}<0.01$,

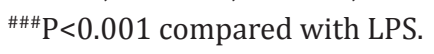
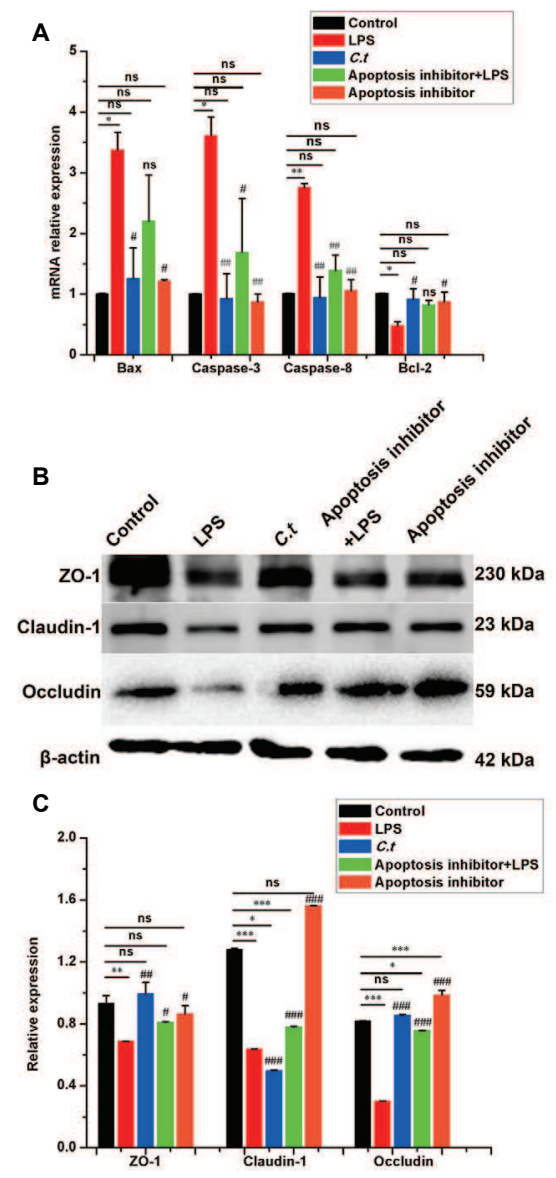


\section{Cellular Physiology Cell Physiol Biochem 2018:46:1779-1792

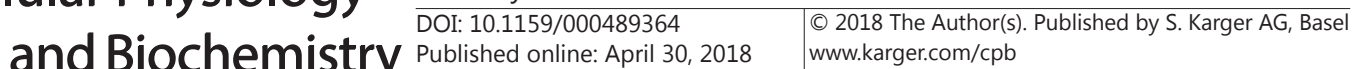 \\ Xiao et al.: C.t Attenuates LPS-Induced Intestial Barrier Dysfunction}

C.t affected the relative mRNA expressions of cell apoptosis-related genes in IPEC-J2 cells

We next analyzed the relative mRNA expression of several apoptotic markers, including caspase-3, caspase-8, Bax, and Bcl-2. As for the expression of the anti-apoptotic gene Bcl2 , the results showed that the relative Bcl-2 expression was significantly decreased with LPS compared with that in the control and C.t treatment groups $(\mathrm{P}<0.05)$. In particular, C.t significantly increased the Bcl-2 expression compared with the control $(\mathrm{P}<0.05)$, signifying its anti-apoptotic effects. Thus, for the LPS + C.t and C.t + LPS treatments, Bcl-2 expressions were higher than with LPS, although the differences were not significant (Fig. 5A). The relative expressions of the pro-apoptotic gene Bax and the apoptotic genes caspase-3/-8 were significantly increased in cells pretreated with LPS compared with the control and C.t treatment groups $(\mathrm{P}<0.01)$. C.t reduced the expression of these apoptosis-related genes (Fig. 5B-D).

\section{C.t protected the intestinal barrier from LPS-induced apoptosis}

The apoptosis inhibitor Z-VAD(OMe)-FMK, a pan-caspase inhibitor, was used in this study to investigate whether $C$.t could protect intestinal barrier function from LPS-induced

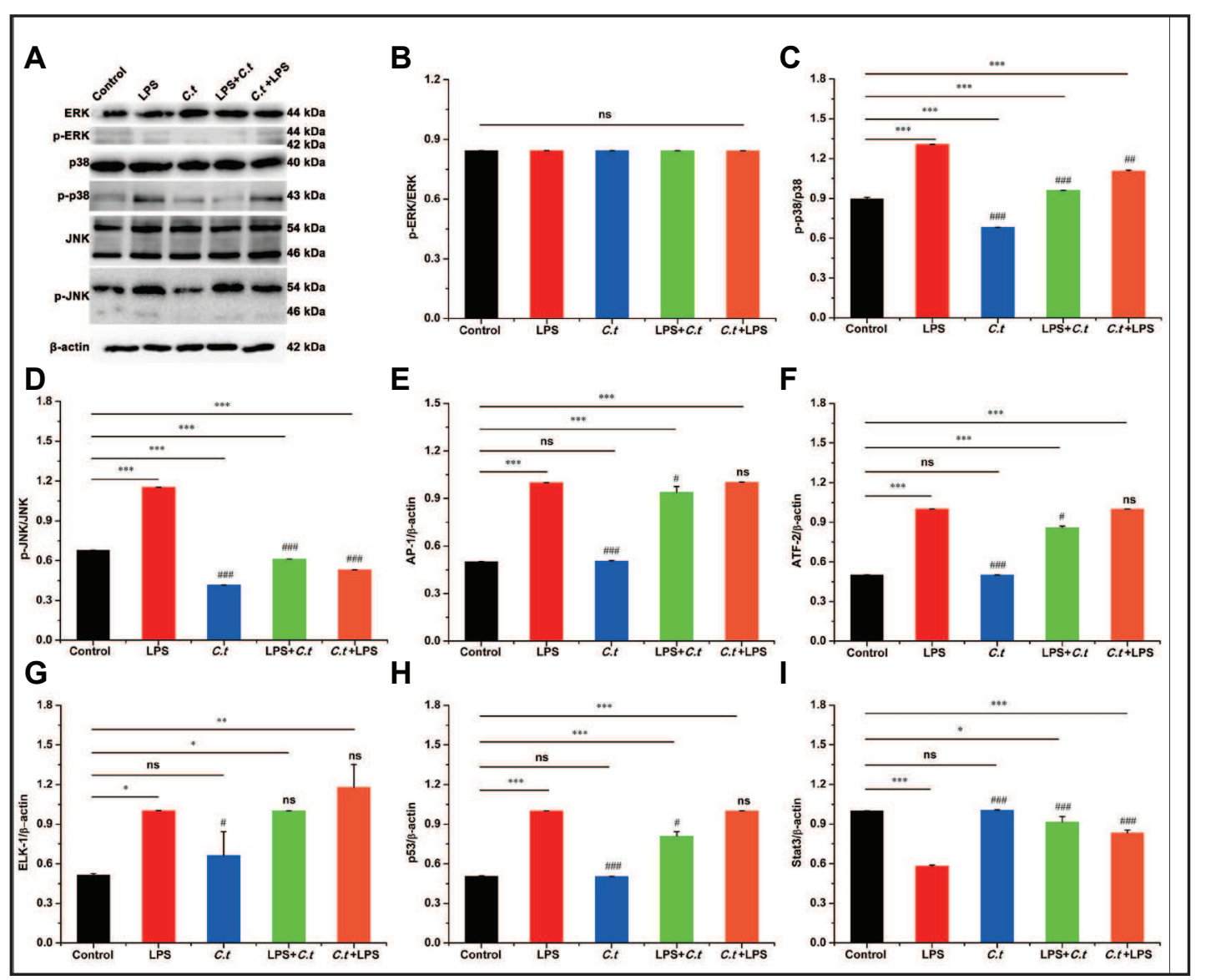

Fig. 7. Clostridium tyrobutyricum (C.t) inhibits LPS-triggered phosphorylation of p38/JNK signaling pathway in IPEC-J2 cells. Cells were cultured in 6-wells plates for $24 \mathrm{~h}$ and then treated with PBS (the control), LPS $(1 \mu \mathrm{g} / \mathrm{mL}$ for $12 \mathrm{~h})$, C.t $\left(10^{8} \mathrm{CFU} / \mathrm{mL}\right.$ for $\left.8 \mathrm{~h}\right)$, LPS + C.t $\left(1 \mu \mathrm{g} / \mathrm{mL}\right.$ LPS for $12 \mathrm{~h}$ followed by $10^{8} \mathrm{CFU} /$ $\mathrm{mL}$ C.t for $8 \mathrm{~h})$, or $C . t+\mathrm{LPS}\left(10^{8} \mathrm{CFU} / \mathrm{mL}\right.$ C.t for $8 \mathrm{~h}$ followed by $1 \mu \mathrm{g} / \mathrm{mL}$ LPS for $\left.12 \mathrm{~h}\right)$. (A) Western blot analysis of ERK, phospho-ERK, p38, phospho-p38, JNK, phospho-JNK; (B-D) Quantitative analysis of the expression of phospho-ERK/ERK, phospho-p38/p38, phospho-JNK/JNK; (E-I) mRNA relative expressions of downstream genes AP-1, ATF-2, ELK-1, p53 and Stat3. Data were expressed as mean \pm SEM ( $n=3) .{ }^{n s} P>0.05$, ${ }^{*} \mathrm{P}<0.05$, ${ }^{* *} \mathrm{P}<0.01$ and ${ }^{* * *} \mathrm{P}<0.001$ compared with the control; ${ }^{n s} \mathrm{P}>0.05,{ }^{\#} \mathrm{P}<0.05,{ }^{\# \#} \mathrm{P}<0.01,{ }^{\# \# \#} \mathrm{P}<0.001$ compared with LPS. Results represented one of the three independent experiments. 


\section{Cellular Physiology Cell Physiol Biochem 2018:46:1779-1792 \begin{tabular}{c|l|l} 
DOI: 10.1159/000489364 & () 2018 The Author(s). Published by S. Karger AG, Basel
\end{tabular} \\ Xiao et al.: C.t Attenuates LPS-Induced Intestial Barrier Dysfunction}

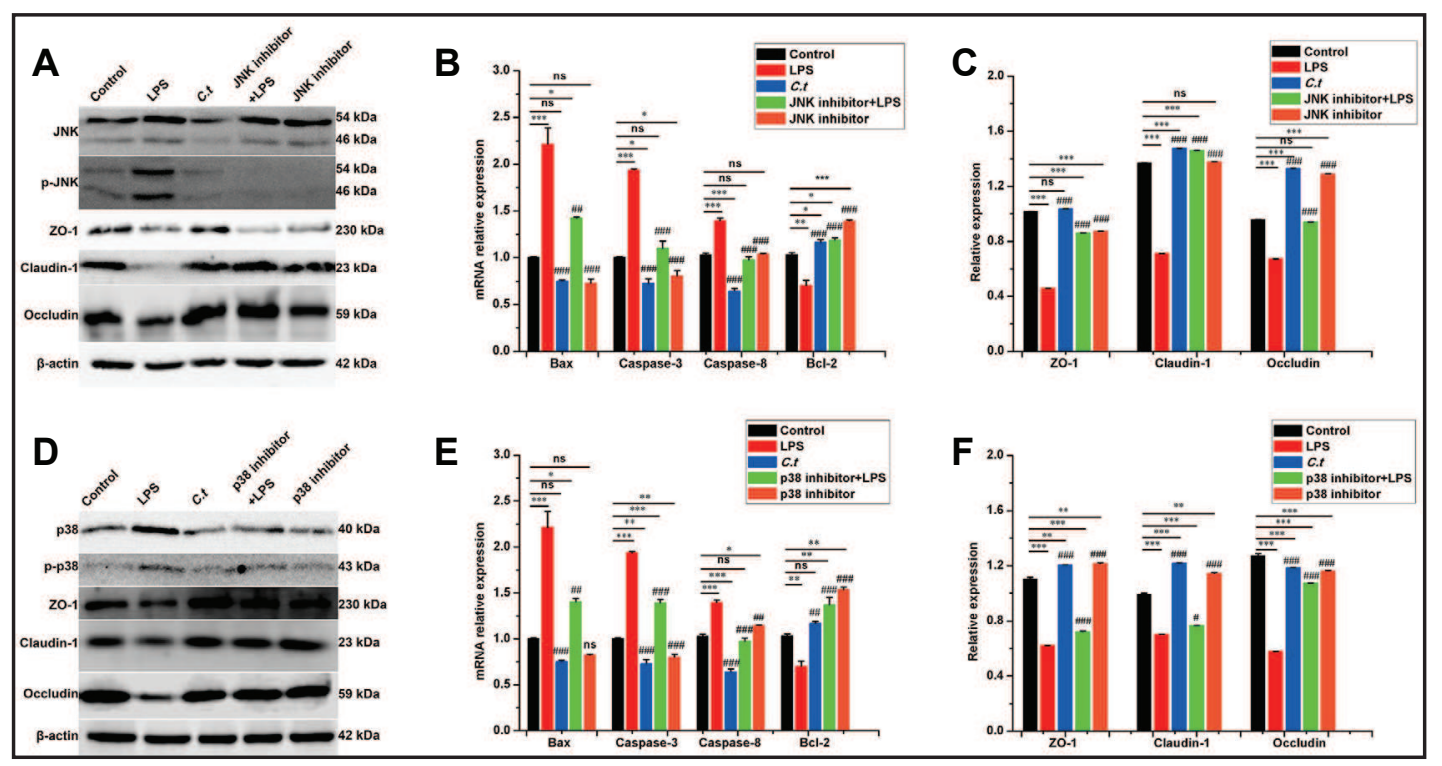

Fig. 8. Clostridium tyrobutyricum (C.t) protect intestinal barrier from LPS-induced apoptosis via p38/JNK signaling pathway in IPEC-J2 cells. Cells were cultured in 6-wells plates for $24 \mathrm{~h}$ and then treated with PBS (the control), LPS $(1 \mu \mathrm{g} / \mathrm{mL}$ for $12 \mathrm{~h})$, C.t $\left(10^{8} \mathrm{CFU} / \mathrm{mL}\right.$ for $\left.8 \mathrm{~h}\right)$, JNK inhibitor + LPS (20 $\mu \mathrm{M}$ apoptosis inhibitor for $1 \mathrm{~h}$ followed by $1 \mu \mathrm{g} / \mathrm{mL}$ LPS for $12 \mathrm{~h}$ ), JNK inhibitor (20 $\mu \mathrm{M}$ apoptosis inhibitor for $1 \mathrm{~h})$, p38 inhibitor + LPS ( $25 \mu \mathrm{M}$ apoptosis inhibitor for $1 \mathrm{~h}$ followed by $1 \mu \mathrm{g} / \mathrm{mL}$ LPS for $12 \mathrm{~h}$ ), or p38 inhibitor (25 $\mu \mathrm{M}$ apoptosis inhibitor for $1 \mathrm{~h}$ ). (A) Western blot bands of JNK, phospho-JNK, ZO-1, Claudin-1, and Occludin; (B, E) mRNA relative expressions of apoptosis related genes Bax, Caspase-3, Caspase-8, and Bcl-2; (C, F) Western blot analysis of ZO-1, Claudin-1, and Occludin; (D) Western blot bands of p38, phospho-p38, Z0-1, Claudin-1, and Occludin. JNK inhibitor SP600125 and p38 inhibitor SB203580 were purchased from MedChem Express, Monmouth Junction, NJ, USA. Data were expressed as mean \pm SEM $(n=5)$. ${ }^{n s} P>0.05,{ }^{*} P<0.05,{ }^{* *} P<0.01$ and ${ }^{* * *} \mathrm{P}<0.001$ compared with the control; ${ }^{\text {ns }} \mathrm{P}>0.05$, ${ }^{\#} \mathrm{P}<0.05$, ${ }^{\# \#} \mathrm{P}<0.01$, ${ }^{\# \# \#} \mathrm{P}<0.001$ compared with LPS.

apoptosis. The relative expressions of the apoptotic genes caspase-3/-8 were significantly decreased in LPS-treated cells after an apoptosis inhibitor was added $(\mathrm{P}<0.05)$. However, no significant differences were observed in the relative expressions of Bax and Bcl-2 between the LPS and apoptosis inhibitor + LPS treatments. These results indicated that an apoptosis inhibitor could partly prevent LPS-induced apoptosis (Fig. 6A). The expressions of TJ proteins were increased dramatically after the addition of the apoptosis inhibitor to LPS-treated cells $(\mathrm{P}<0.05)$, which were similar to the results of $C . t$-treated cells (Fig. 6B and C).

\section{C.t suppressed LPS-induced apoptosis by inhibiting the p38 and JNK signaling pathways}

To elucidate the mechanisms underlying the effects of C.t on LPS-induced apoptosis, we examined the effects of $C . t$ on the MAPK signaling pathway. Phosphorylation of p38 (p-p38) and JNK (p-JNK) was observed after LPS treatment of cells. However, C.t inhibited the LPSinduced phosphorylation of p-p38 and p-JNK (Fig. 7A-D). We then measured the relative mRNA expressions of downstream genes in this pathway. The mRNA levels of AP-1, ATF-2, ELK-1, and $\mathrm{p} 53$ were increased $(\mathrm{P}<0.05)$ and that of Stat 3 was decreased $(\mathrm{P}<0.001)$ in cells treated with LPS compared with the control, whereas C.t inhibited these changes (Fig. 7E-I).

Pharmacological inhibitors of p38 (SB203580) and JNK (SP600125) were used to investigate the underlying mechanisms of the protective effects of C.t on LPS-induced apoptosis in IPEC-J2 cells. The concentrations of p-p38 and p-JNK were suppressed when cells were treated with inhibitors or inhibitors + LPS (Fig. 8A and D). The mRNA levels of the anti-apoptotic gene Bcl-2 were increased in cells treated with inhibitors or with inhibitors + LPS compared with cells treated with LPS alone $(\mathrm{P}<0.05)$. In addition, relative mRNA expressions of apoptosis-related genes, including Bax, caspase-3, and caspase-8, were significantly decreased when inhibitors were added to the cells $(\mathrm{P}<0.01$; Fig. 8B and 


\section{Cellular Physiology \\ Cell Physiol Biochem 2018;46:1779-1792 and Biochemistry

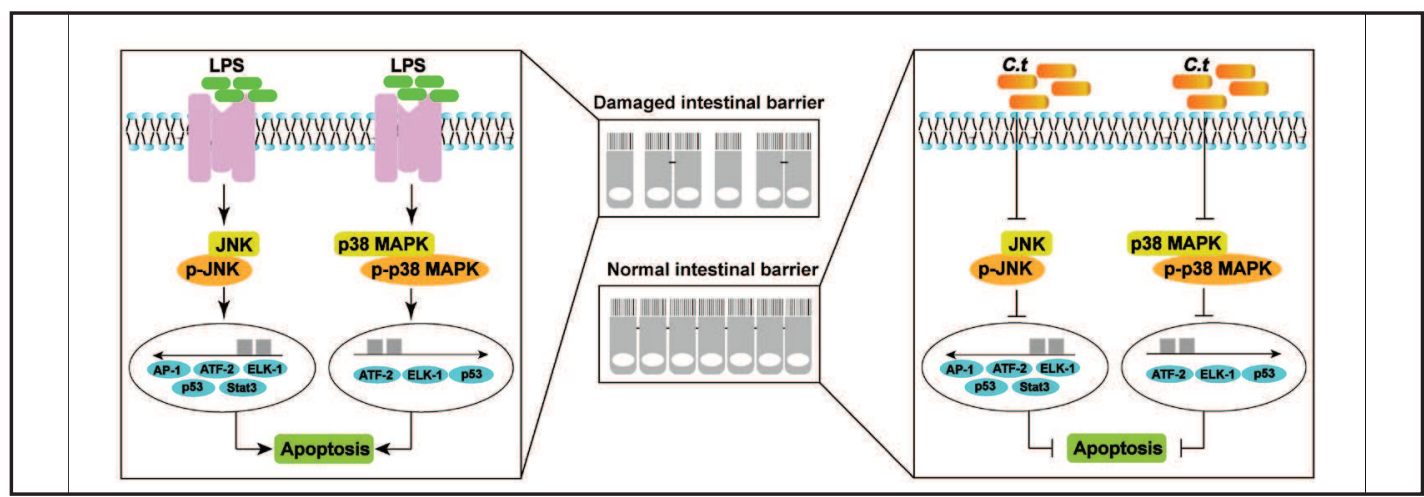

Fig. 9. Proposed model of Clostridium tyrobutyricum (C.t) protect intestinal barrier against LPS-induced apoptosis via inhibiting the phosphorylation of p38/JNK in IPEC-J2 cells. p38/JNK are activated in the presence of specific stress stimuli, LPS. The phosphorylated p38/JNK active their downstream genes such as AP1, ATF-2, ELK-1, p53 and Stat3, which induce apoptosis, eventually, result in intestinal permeability increasing and intestinal barrier damage (left panel and upper of the medium panel). The phosphorylation of p38/ JNK and the expression of downstream genes are inhibited by C.t, which suppresses apoptosis and protects the normal intestinal barrier function (right panel and lower of the medium panel).

E). TJ proteins levels were also determined to verify whether $C . t$ could protect intestinal barrier function from LPS-induced apoptosis via the p38/JNK signaling pathway. The results showed that expressions of TJ proteins were increased when p38/JNK signaling pathways were switched off $(\mathrm{P}<0.05$; Fig. 8C and F).

\section{Discussion}

C.t, a Gram-positive and strictly anaerobic bacterium, has received much attention from the dairy and chemical synthesis industries because of its efficiency in butyric acid production $[19,20]$. However, the role of C.t in animal models or mammalian cells has not yet been reported. In this work, the biological function of C.t was investigated in vitro, with the results showing that $C$.t could protect the intestinal barrier from LPS-induced apoptosis in IPEC-J2 cells.

The intestinal epithelium, which represents the largest interface in the body, plays several important roles in the absorption of nutrients and prevention of water and electrolyte loss $[21,22]$. In particular, the intestinal barrier can separate the internal milieu from the external environment via cell-cell adhesion and intercellular junctions that direct morphogenesis and maintain tissue integrity [2]. Intestinal permeability is controlled by epithelial adherens junctions and TJs, with the increased intestinal permeability contributing to the severity of some diseases, such as inflammatory bowel disease and irritable bowel syndrome [21]. In the present study, anin vitro-simulated intestinal barrier was established by culturing IPEC-J2 cells in Transwells. LPS has a negative effect on the TEER values and TJ protein contents of IPEC-J2 cells, ultimately resulting in increased permeability and intestinal barrier dysfunction $[23,24]$. Many reports have also revealed that the TEER values and TJ protein expressions markedly decreased after cells were treated with LPS for 12 or $24 \mathrm{~h}[7,25]$. In our study, we successfully constructed a model of LPS-induced increased permeability. The TEER values decreased to their lowest level and the expression of these TJ proteins was completely reduced after the IPEC-J2 cells were treated with LPS for $20 \mathrm{~h}$. In contrast, C.t stably maintained the TEER values and increased the expression of the TJ protein sat $20 \mathrm{~h}$. The decrease in the TEER values and TJ protein expression were also inhibited by C.t. Our further research on the expression of TJ proteins in cells treated with LPS for only $12 \mathrm{~h}$ or with $C . t$ for $8 \mathrm{~h}$ also verified the protective function of C.t. These results indicate that C.t protected the intestinal barrier from the LPS-induced increase in intestinal permeability. 


\section{Cellular Physiology Cell Physiol Biochem 2018;46:1779-1792 and Biochemistry Published online: April 30, $2018 \quad \begin{aligned} & \text { O } 2018 \text { The Author } \\ & \text { www.karger.com/cpp }\end{aligned}$ \\ Xiao et al.: C.t Attenuates LPS-Induced Intestial Barrier Dysfunction}

Apoptosis, which is a type of programmed cell death involving the activation of apoptotic caspases, can be initiated by a variety of stimuli arising from receptors on the cell surface or from the detection of events within the cell [26]. Tumor necrosis factor (TNF) or LPS stimulation increase apoptosis and consequent cell shedding which are associated with barrier loss [27]. We noticed in the present study that, after treatment with LPS, cells showed nuclear and cytoplasmic condensation, typical characteristics of apoptosis. LPS, which is a major component in the outer monolayer of most Gram-negative bacteria, can induce apoptosis and disturb intestinal integrity in IPEC-J2 cells [28]. Thus, in the present study, we hypothesized that C.t could inhibit LPS-induced apoptosis and ultimately protect the intestinal barrier. We found that LPS induced apoptosis at $12 \mathrm{~h}$ and that C.t efficiently inhibited this phenomenon. The relative mRNA expression levels of apoptosis-related genes, including Bcl-2, Bax, and caspase-3/-8, were also measured in this study; their levels were consistent with the results of the Annexin V-FITC/PI assay and flow cytometry. Moreover, intestinal barrier function was improved when LPS-induced apoptosis was prevented by a pharmacological apoptotic inhibitor. Our results qualitatively and quantitatively indicated that C.t may protect intestinal barrier function by markedly suppressing LPS-induced apoptosis in IPEC-J2 cells.

MAPKs play essential roles in some physiological cell processes, including inflammation, stress, growth, differentiation, and death. ERK1/2 are mostly activated by growth factors, such as epidermal growth factor and nerve growth factor, which play central roles in the control of cell proliferation $[29,30]$. While p38 and JNK, known as stress-activated protein kinase, are strongly activated by various cellular stresses, such as heat shock and oxidative stress, TNF- $\alpha$ and LPS, which play roles in cell proliferation and survival, are associated with the induction of apoptosis by cellular stresses [30]. In the present study, p38 and JNK phosphorylation occurred after cells were treated with LPS for $12 \mathrm{~h}$. The major functional role of phosphorylated p38 and JNK lies in mediating the downstream substrates involved in the cell cycle and apoptosis [29]. Our results also suggest that the relative mRNA expressions of downstream genes of the p38 and JNK signaling pathways, including AP-1, ATF-2, ELK1 , and p53, were increased and that Stat3 expression was dramatically decreased after cells were treated with LPS, which may activate caspases and induce apoptosis [31, 32]. Pharmacological inhibitors were used to switch off the activation of p38/JNK signaling pathways; we found that these inhibitors could restrain LPS-induced apoptosis and thus improve intestinal barrier function. Therefore, we speculated that $C . t$ inhibited LPS-induced apoptosis by depressing the p38/JNK signaling pathway (Fig. 9). However, the molecular basis of how C.t suppresses the activity of the p38/JNK signaling pathway remains to be investigated.

\section{Conclusion}

Our findings suggest that $C . t$ could protect against the LPS-induced increase in intestinal permeability and inhibit LPS-induced intestinal apoptosis via the $\mathrm{p} 38 / \mathrm{JNK}$ signaling pathway in IPEC-J2 cells. These results suggest $C . t$ is a potential probiotic additive for protecting the intestinal barrier and preventing diarrhea in early weaned piglets.

\section{Acknowledgements}

This study was supported by the Project of Ministry of Agriculture (948) (Grant No. 2014-Z27).

We would like to thank Shaojuan Liu from Institute of Subtropical Agriculture, Chinese Academy of Sciences for IPEC-J2 cells giving. We are grateful to Hongyun Liu and Wei Lan from Institute of Dairy Science, College of Animal Sciences for fluorescence microscope guidance and Dr. Chao Sun from Agricultural, Biological and Environmental Test Center for assistance with flow cytometry, Zhejiang University. 


\section{Cellular Physiology Cell Physiol Biochem 2018;46:1779-1792 \begin{tabular}{c|l} 
DOI: 10.1159/000489364 & $\begin{array}{l}\text { () 2018 The Author(s). Published by S. Karger AG, Basel } \\
\text { www.karger.com/cpb }\end{array}$
\end{tabular} \\ Xiao et al.: C.t Attenuates LPS-Induced Intestial Barrier Dysfunction}

\section{Disclosure Statement}

No conflict of interest exists.

\section{References}

1 Suzuki T: Regulation of intestinal epithelial permeability by tight junctions. Cell Mol Life Sci 2013;70:631659.

2 Choi W, Yeruva S, Turner JR: Contributions of intestinal epithelial barriers to health and disease. Exp Cell Res 2017;358:71-77.

-3 Wijtten PJ, van der Meulen J, Verstegen MW: Intestinal barrier function and absorption in pigs after weaning: a review. Brit J Nutr 2011;105:967-981.

-4 Lu RY, Yang WX, Hu YJ: The role of epithelial tight junctions involved in pathogen infections. Mol Biol Rep 2014;41:6591-6610.

5 Landy J, Ronde E, English N, Clark SK, Hart AL, Knight SC, Ciclitira PJ, Al-Hassi HO: Tight junctions in inflammatory bowel diseases and inflammatory bowel disease associated colorectal cancer. World J Gastroent 2016;22:3117-3126.

-6 Surendran Nair M, Amalaradjou MA, Venkitanarayanan K: Antivirulence properties of probiotics in combating microbial pathogenesis. Adva Appl Microbiol 2017;98:1-29.

7 Yang F, Wang A, Zeng X, Hou C, Liu H, Qiao S: Lactobacillus reuteri I5007 modulates tight junction protein expression in IPEC-J2 cells with LPS stimulation and in newborn piglets under normal conditions. BMC Microbiol 2015;15:32.

8 Tian Z, Liu X: Enterococcus faecium HDRsEf1 Protects the Intestinal Epithelium and Attenuates ETEC Induced IL-8 Secretion in Enterocytes. Mediators Inflamm 2016;7474306.

-9 Whitfield C, Trent MS: Biosynthesis and export of bacterial lipopolysaccharides. Annu Rev Biochem 2014;83:99-128.

10 De Plaen IG: Inflammatory signaling in necrotizing enterocolitis. Clin Perinatol 2013;40:109-124.

-11 Zhang LB, Man ZT, Li W, Zhang W, Wang XQ Sun S: Calcitonin protects chondrocytes from lipopolysaccharide-induced apoptosis and inflammatory response through MAPK/Wnt/NF-kappaB pathways. Mol Immunol 2017;87:249-257.

-12 Talavera MM, Kralik N, Jin Y, Chen B, Liu Y, Nelin LD: Mitogen-activated protein kinase phosphatase-1 prevents lipopolysaccharide-induced apoptosis in immature rat intestinal epithelial cells. Pediatr Res 2015;78:128-136.

-13 Fu HX, Yang ST, Wang MQ, Wang JF, Tang IC: Butyric acid production from lignocellulosic biomass hydrolysates by engineered Clostridium tyrobutyricum overexpressing xylose catabolism genes for glucose and xylose co-utilization. Bioresource Techn 2017;234:389-396.

14 Mosmann T: Rapid colorimetric assay for cellular growth and survival: application to proliferation and cytotoxicity assays. J Immunol Methods 1983;65:55-63.

15 Gorogh T, Quabius ES, Georgitsis A, Hoffmann M, Lippross S: Sequential activation of the AKT pathway in human osteoblasts treated with Oscarvit: a bioactive product with positive effect both on skeletal pain and mineralization in osteoblasts. BMC Musculoskel D 2017;18:500.

16 Vergauwen H: The IPEC-J2 Cell Line; in Verhoeckx K, Cotter P, López-Expósito I, Kleiveland C, Lea T, Mackie A, Requena T, Swiatecka D, Wichers H (eds): The Impact of Food Bioactives on Health: in vitro and ex vivo models. Cham, Springer International Publishing, 2015, pp 125-134.

-17 Song D, Cheng Y, Li X, Wang F, Lu Z, Xiao X, Wang Y: Biogenic Nanoselenium Particles Effectively Attenuate Oxidative Stress-Induced Intestinal Epithelial Barrier Injury by Activating the Nrf2 Antioxidant Pathway. ACS Appl Mater Inte 2017;9:14724-14740.

18 Ginzinger DG: Gene quantification using real-time quantitative PCR: an emerging technology hits the mainstream. Exp Hematol 2002;30:503-512. 


\section{Cellular Physiology Cell Physiol Biochem 2018;46:1779-1792 \begin{tabular}{l|l|l} 
DOI: 10.1159/000489364 & $\begin{array}{l}\text { () 2018 The Author(s). Published by S. Karger AG, Basel } \\
\text { www.karger.com/cpb }\end{array}$
\end{tabular} \\ Xiao et al.: C.t Attenuates LPS-Induced Intestial Barrier Dysfunction}

19 D'Incecco P, Faoro F, Silvetti T, Schrader K, Pellegrino L: Mechanisms of Clostridium tyrobutyricum removal through natural creaming of milk: A microscopy study. J Dairy Sci 2015;98:5164-5172.

20 Lavilla M, Marzo I, de Luis R, Perez MD, Calvo M, Sanchez L: Detection of Clostridium tyrobutyricum spores using polyclonal antibodies and flow cytometry. J Appl Microbiol 2010;108:488-498.

-21 Lechuga S, Ivanov AI: Disruption of the epithelial barrier during intestinal inflammation: Quest for new molecules and mechanisms. Biochim Biophys Acta 2017;1864:1183-1194.

-22 Bischoff SC, Barbara G, Buurman W, Ockhuizen T, Schulzke JD, Serino M, Tilg H, Watson A, Wells JM: Intestinal permeability-a new target for disease prevention and therapy. BMC Gastroenterolo 2014;14:189.

23 Geens MM, Niewold TA: Preliminary Characterization of the Transcriptional Response of the Porcine Intestinal Cell Line IPEC-J2 to Enterotoxigenic Escherichia coli, Escherichia coli, and E. coli Lipopolysaccharide. Comp Funct Genom 2010;2010:469583.

24 Gao K, Wang C, Liu L, Dou X, Liu J, Yuan L, Zhang W, Wang H: Immunomodulation and signaling mechanism of Lactobacillus rhamnosus GG and its components on porcine intestinal epithelial cells stimulated by lipopolysaccharide. J Microbiol Immunol Infect 2017;50:700-713.

-25 Yan H, Ajuwon KM: Butyrate modifies intestinal barrier function in IPEC-J2 cells through a selective upregulation of tight junction proteins and activation of the Akt signaling pathway. Plos One 2017;12:e0179586.

26 Miao EA, Rajan JV, Aderem A: Caspase-1-induced pyroptotic cell death. Immunol Rev 2011;243:206-214.

27 Gunther C, Buchen B, He GW, Hornef M, Torow N, Neumann H, Wittkopf N, Martini E, Basic M, Bleich A, Watson AJ, Neurath MF, Becker C: Caspase-8 controls the gut response to microbial challenges by Tnfalphadependent and independent pathways. Gut 2015;64:601-610.

28 Cui Y, Liu L, Dou X, Wang C, Zhang W, Gao K, Liu J, Wang H: Lactobacillus reuteri ZJ617 maintains intestinal integrity via regulating tight junction, autophagy and apoptosis in mice challenged with lipopolysaccharide. Oncotarget 2017;8:77489-77499.

29 Sidarala V, Kowluru A: The Regulatory Roles of Mitogen-Activated Protein Kinase (MAPK) Pathways in Health and Diabetes: Lessons Learned from the Pancreatic beta-Cell. Recent Pat Endocr Metab Immune Drug Discov 2017;10:76-84.

-30 Cargnello M, Roux PP: Activation and function of the MAPKs and their substrates, the MAPK-activated protein kinases. Microbiol Mol Biol Rev 2011;75:50-83.

-31 Bogoyevitch MA, Kobe B: Uses for JNK: the many and varied substrates of the c-Jun.N-terminal kinases. Microbiol Mol Biol Rev 2006;70:1061-1095.

32 Dhanasekaran DN, Reddy EP: JNK signaling in apoptosis. Oncogene 2008;27:6245-6251. 